Ann. Biol. anim. Bioch. Biophys., 1979, 19 (6), 1725-1736.

\title{
Effect of type and amount of dietary fat on bile flow and composition in rats.
}

\author{
par Micheline BOQUILLON, Jacqueline CLÉMENT \\ with the technical assistance of Marguerite-Marie BOUTILLON, Monique CHABIN \\ Laboratoire de Physiologie onimale ef de la Nutrition, LA, CNRS 273, \\ U. E. R. Nutrition, 21004 Dijon Cedex France.
}

Summary. The output of bile and biliary components (biliary salts, phospholipids, cholesterol) during the first hour after bile duct catheterization have been determined in conscious rats fed either a commercial diet or semi-purified diets containing 7 or 20 p. 100 of corn oil or 20 p. 100 of lard or mutton tallow. In those conditions, there was no significant difference in bile or biliary salts output among the various experimental groups. On the contrary, the output of cholesterol and, to a lesser extent, that of phospholipids augmented when the percentage of corn oil in the diet was increased from 7 to $20 \mathrm{p} .100$; as compared to the former group, the output of these two components was lower in the «lard 》 and « mutton tallow » groups. Among the groups receiving the high-fat diets, absolute and relative biliary phospholipid concentrations were highest in the lard group, while the absolute biliary cholesterol concentration was identical in the lard and mutton tallow groups but lower than in the « corn oil » group. The relative bile salts concentrations were significantly different in the groups fed the semi-purified diets; the highest value was found in the mutton tallow and corn oil groups (20 p. 100). The proportions of biliary lecithins, as compared to total phospholipids, were constant in the different groups, but the fatty acid patterns of biliary lecithins varied according to the diet fed. During the $6 \mathrm{hrs}$ that the enterohepatic circulation was interrupted, biliary salts and phospholipid outputs decreased from the beginning of collection to the end, particularly when the initial value was higher ; the decrease of cholesterol output was noticeable only in rats fed corn oil. From these experiments, in which dietary protein content remained constant at 17 p. 100, we concluded that dietary fats generally interfere in the synthesis and secretion of biliary components ; feeding 20 p. 100 of corn oil in the diet particularly led to increased phospholipid and cholesterol excretion through the bile. In rats fed a 20 p. 100 lard diet, biliary phospholipid output and concentration increased while the bile flow rate tended to decrease.

\section{Introduction}

Polyunsaturated fats may lower plasma cholesterol levels (Kinsell et al., 1952 ; Armstrong et al., 1957 ; Quacquenbush and Pawlowski, 1960). One of the explanations

Abbreviations : BS : bile salts, PL : diacylphosphatides, PC : phosphatidylcholines, Ch : cholesterol. 
of this decrease is an increased excretion of $\mathrm{Ch}$ and its metabolites, such as BS, through the bile. Not taking into account the dietary fat rates, this finding has been demonstrated in chicks (Lindsay et al., 1969), dogs (Wheeler and King, 1972), rats (Paul and Ganguly, 1976), monkeys (Redinger et al., 1971 ; Dowling ef al., 1971) and men (Byers and Friedman, 1958 ; Avigan and Steinberg, 1965 ; Shioda et al., 1967 ; Sodhi ef al., 1967 ; Moore et al., 1968). The biliary acid turnover would be more rapid when unsaturated fats are fed (Gordon et al., 1964 ; Lindstedt et al., 1965 ; McGovern and Quacquenbush, 1973). Only two papers (monkeys : Dowling ef al., 1971 ; rats : Davis et al., 1977) have reported the effect of different amounts of dietary fat on bile flow and on BS and biliary $C h$ secretion.

The study of the variations in biliary PL concentration compared with changes in BS and biliary $\mathrm{Ch}$ concentrations, according to the type of dietary fat, has been relatively neglected, although data on biliary $\mathrm{PL}$ concentration as related to dietary fats were obtained on rats (Paul and Ganguly, 1976) and monkeys (Redinger et al., 1971 ; Osuga ef al., 1976). However, the biliary concentrations of PC and BS, which are potential $\mathrm{Ch}$ solubilizing agents, play an important role in biliary $\mathrm{Ch}$ concentration. Further investigation has seemed to indicate that bile acid secretion does not entirely account for all of the canalicular bile formation (Klaassen, 1970, 1971).

The present study was designed to provide more information on bile flow and the biliary excretion of PL, Ch and BS in rats receiving diets containing 7 or 20 p. 100 of fats with different saturated and unsaturated fatty acid content during 3 weeks. The bile collected in rats fed a commercial diet was also analyzed because the data could prove useful to many researchers using the diet. The protein content of all the diets was 17 p. 100 by weight.

\section{Material and methods.}

Animal treatment. - Male Wistar rats (170 to $185 \mathrm{~g}$ ) maintained on a commercial dief (UAR, Villemoisson, France) containing 3 p. 100 lipid (with linoleic acid representing 50 p. 100 of the total fatty acids), 17 p. 100 protein and 59 p. 100 starch and sucrose were divided into 5 groups of 12 animals each. Group $C$ continued to receive the commercial diet; the other groups were given a semi-synthetic diet containing 17 p. 100 casein and either 43 p. 100 carbohydrate and 20 p. 100 fat (corn oil, lard or mutton tallow; groups $\mathrm{CO}_{20}, \mathrm{~L}_{20}$ and $\mathrm{MT}_{20}$, respectively) or $56 \mathrm{p} .100$ carbohydrate and 7 p. 100 corn oil (group $\mathrm{CO}_{7}$ ). The fatty acid composition of the fats is shown in table 1. Diets and water were given ad libitum, and the diets were fed for 3 weeks to obtain a steady state of bile composition.

In collecting the bile, we followed an identical schedule to prevent daily fluctuations of biliary excretion and composition (Ho and Drummond, 1975).

The bile duct was catheterized under ether anesthesia in non-fasting rats between 10 and 11 a.m., and $2 \mathrm{ml}$ of saline solution was given by gastric intubation. Each animal was kept in a restraining cage. Bile collection directly into a graduated centrifuge tube at 1-hour intervals for $6 \mathrm{hrs}$ was started immediately after the operation ; from that time, no food or drink was given. A $6 \mathrm{hrs}$ period was selected because bile acid secretion continues in the rat during this period (Myant and Eder, 1961 ; Shefer 
ef al., 1969). If the bile flow of any animal proved to be intermittent, the experiment was discarded.

\section{TABLE 1}

Fatty acid composition of dietary fats (in moles)

\begin{tabular}{|c|c|c|c|}
\hline \multirow{2}{*}{ Fatty acids } & \multicolumn{3}{|c|}{ Dietary fats } \\
\hline & Corn oil & Lard & Mutton fallow \\
\hline$<16: 0 \ldots$ & & 2.3 & 5.7 \\
\hline $16: 0 \ldots$ & 12.5 & 29.9 & 23.6 \\
\hline $16: 1 \quad \ldots$ & 0.6 & 5.4 & 3.3 \\
\hline $18: 0 \quad \ldots$ & 1.9 & 5.9 & 26.3 \\
\hline $18: 1 \ldots$ & 28.9 & 46.0 & 36.2 \\
\hline $18: 2 \ldots$ & 54.7 & 8.8 & 4.0 \\
\hline$>18: 2 \ldots \ldots$ & 1.4 & 1.7 & 0.9 \\
\hline Saturated .. & 14.4 & 38,1 & 55.6 \\
\hline Unsaturated .......... & 85.6 & 61.9 & 44.4 \\
\hline
\end{tabular}

Extraction and analysis of lipids. - The bile sample lipids were extracted according to Folch, Lees and Sloane-Stanley (1957). Aliquots of total lipids were used to determine lipid phosphorus (Machebœuf and Delsal, 1943) and Ch (Delsal, 1944). PL mass was calculated from the amount of $P \times 25$. The PC were separated by TLC and their fatty acid composition was determined by GLC (Boucrot, 1972). Total bile acid concentration was ascertained by hydroxysteroid dehydrogenase (Talalay, 1960) using purified enzyme obtained from Worthington Biochemical Corporation. Some results were compared by an analysis of variance. When the analysis indicated that the Fisher-Snedecor's $f$-test was significant $(P<0.05)$, the means were compared using the Newman Keul method $(P<0.05)$ and calculated by a Olivetti $P 602$ program to study the rate of dietary lipid $\left(\mathrm{CO}_{7}\right.$ vs. $\left.\mathrm{CO}_{20}\right)$ and the type of dietary lipid $\left(\mathrm{CO}_{20}\right.$, $\mathrm{L}_{20}, \mathrm{MT}_{20}$ ).

\section{Results.}

The food intake was similar in groups $\mathrm{CO}_{20}, \mathrm{~L}_{20}$ and $\mathrm{MT}_{20}(15 \mathrm{~g} /$ day $/$ rat $)$; it was $25 \mathrm{~g} /$ day/rat in group $\mathrm{C}$, and no evaluation was made for group $\mathrm{CO}_{7}$. At the time the rats were killed, the mean body weight of the first three groups was similar 
$(270 \pm 17 \mathrm{~g})$, whereas for groups $\mathrm{C}$ and $\mathrm{CO}_{7}$, it was $240 \pm 12 \mathrm{~g}$ and $290 \pm 14 \mathrm{~g}$, respectively.

A. Bile flow and composition of bile collected during the first hour after bile duct catheterization (tables 2 and 3).

In the first bile collection, there was no significant difference among the groups as to bile flow rate and BS output; however, group $\mathrm{CO}_{20}$ tended to show the highest values $(0.92 \mathrm{ml}, 31.6 \mu$ moles, respectively). On the contrary, there were significant

TABLE 2

Bile flow and output of BS, Ch and PL in bile collected during the first hour ofter bile duct catheterization in rats fed various diets

\begin{tabular}{|c|c|c|c|c|}
\hline Groups & $\begin{array}{l}\text { Volume } \\
\qquad(\mathrm{ml})\end{array}$ & $\begin{array}{c}\text { BS } \\
(\mu \text { moles })\end{array}$ & $\begin{array}{c}\mathrm{Ch} \\
\text { (umoles) }\end{array}$ & $\begin{array}{c}\mathrm{PL} \\
\text { ( } \mu \text { moles) }\end{array}$ \\
\hline 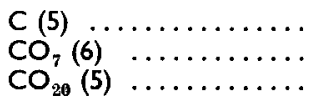 & $\begin{array}{l}0.64 \pm 0.10 \\
0.74 \pm 0.10 \\
0.92 \pm 0.06 \\
\end{array}$ & $\begin{array}{l}18.9 \pm 4.9 \\
27.6 \pm 4.9 \\
31.6 \pm 2.9 \\
\end{array}$ & $\begin{array}{l}0.23 \pm 0.05 \\
0.29 \pm 0.05 \\
1.16 \pm 0.08 \\
\end{array}$ & $\begin{array}{l}3.4 \pm 0.7 \\
4.9 \pm 0.7 \\
7.3 \pm 0.4\end{array}$ \\
\hline $\mathrm{L}_{20}(5) \ldots \ldots \ldots \cdots \cdots \cdots$ & $\begin{array}{l}\overline{0.60 \pm 0.03} \\
0.77 \pm 0.10\end{array}$ & $\begin{array}{l}15.9 \pm 2.2 \\
29.0 \pm 4.1\end{array}$ & $\begin{array}{l}0.37 \pm 0.07 \\
0.46 \pm 0.06\end{array}$ & $\begin{array}{l}\overline{5.6 \pm 0.4} \\
5.1 \pm 0.4\end{array}$ \\
\hline $\begin{array}{l}F\left({ }^{1}\right) \ldots \ldots \ldots \ldots \ldots \ldots \\
\text { Comparison between } \\
\text { groups }\left({ }^{2}\right) \ldots \ldots \ldots \ldots \ldots\end{array}$ & $2.36 \mathrm{~ns}$ & $2.59 \mathrm{~ns}$ & $\begin{array}{c}35.31 * * \\
\mathrm{CO}_{20}>\mathrm{CO}_{7} \\
\mathrm{CO}_{20}>\mathrm{L}_{20} \simeq \mathrm{MT}_{20}\end{array}$ & $\begin{array}{c}\mathrm{CO}_{20}^{4.94 *}>\mathrm{CO}_{7} \\
\mathrm{CO}_{20}>\mathrm{L}_{20} \simeq \mathrm{MT}_{20}\end{array}$ \\
\hline
\end{tabular}

Each value represents the mean $\pm S E M$.

() Number of rats.

(1) ns $==$ non significant $(P>0.05)$. $* P<0.05 . * * P \leqslant 0.01$.

$\left({ }^{2}\right)>$ significantly different $(P \leqslant 0.05) . \simeq$ not significantly different $(P>0.05)$.

differences in the output of $\mathrm{Ch}$ and PL among the groups. Thus, in rats fed the corn oil diet $\left(\mathrm{CO}_{20}\right)$ the output of $\mathrm{Ch}$ was fourfold and that of $\mathrm{PL} 1.5$ time more than the values obtained in group $\mathrm{CO}_{7}$. In rats fed high-fat diets, $\mathrm{Ch}$ output in group $\mathrm{CO}_{20}$ was threefold that of groups $L_{20}$ and $M T_{20}$; the $P L$ output was also higher in group $C_{20}$ than in the other two groups.

No significant difference in the total bile concentration and the absolute BS concentration (table 3) was seen among the different groups. On the contrary, considerable differences in absolute $\mathrm{Ch}$ and $\mathrm{PL}$ concentrations were obtained which were lower in group $\mathrm{CO}_{7}$ than in group $\mathrm{CO}_{20}$. Absolute $\mathrm{Ch}$ concentrations were similar in groups $L_{20}$ and $M T_{20}$, and lower than in group $C_{20}$; that of $P L$ was in the order $\mathrm{L}_{20}>\mathrm{CO}_{20}>\mathrm{MT}_{20}$.

Except for group $L_{20}$, the differences in relative bile composition in the various groups were less pronounced than those of absolute composition. The relative BS and $\mathrm{Ch}$ concentrations were significantly different and higher in group $\mathrm{CO}_{20}$ than in group $\mathrm{CO}_{7}$, but that of $\mathrm{PL}$ was not significantly different in the two groups. In rats 


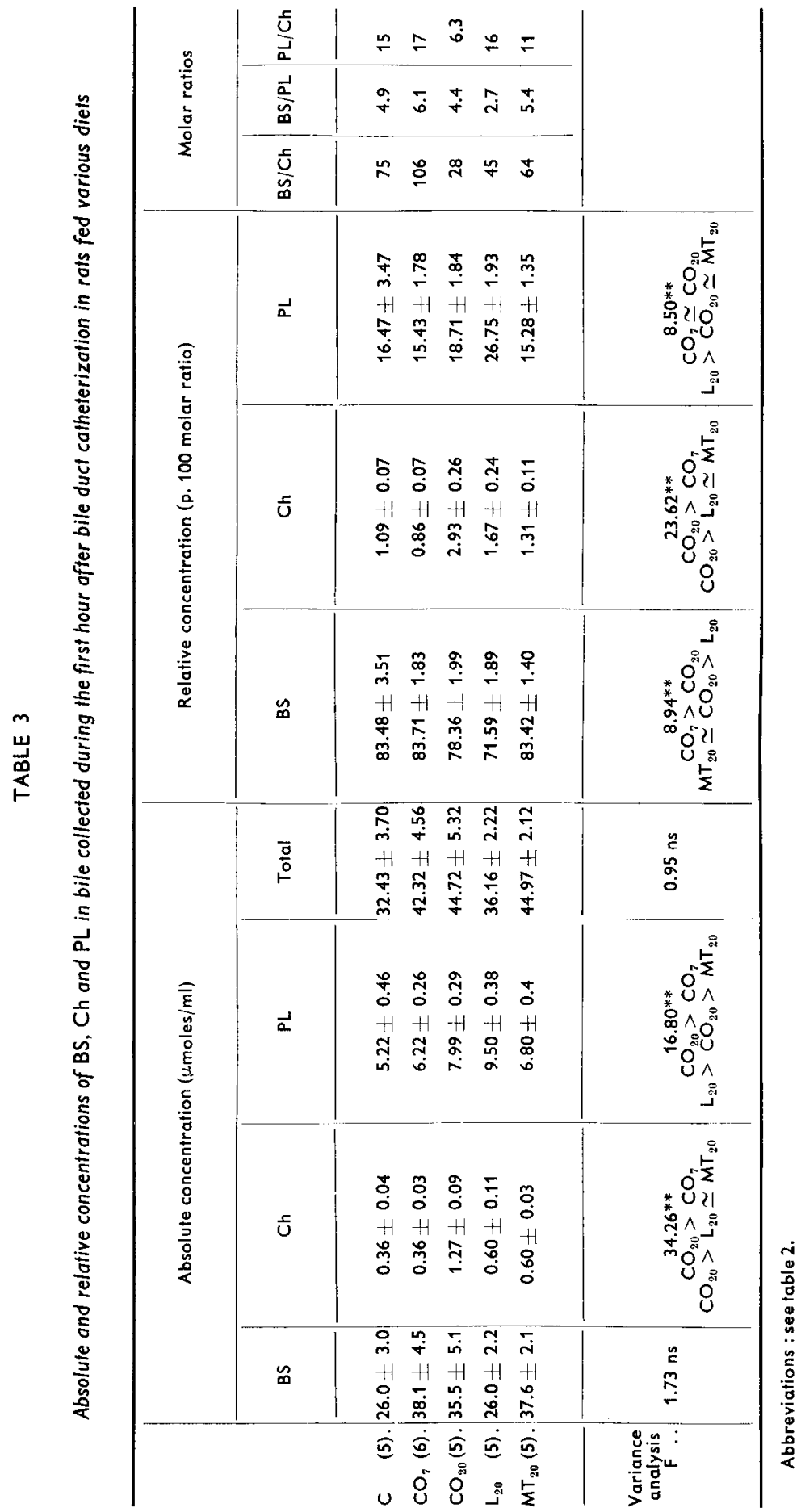


fed high-fat diets, the relative $\mathrm{Ch}$ concentrations were in the order $\mathrm{CO}_{20}>\mathrm{L}_{20} \simeq$ $M T_{20}$, and those of $P L$ were in the order $L_{20}>C_{20} \simeq M T_{20}$.

In group $C$ the absolute concentrations of the three biliary components were lower than in the other groups, and their relative BS and PL concentrations were close to those found for groups $\mathrm{CO}_{7}$ and $\mathrm{MT}_{20}$. (table 4).

B. Fatty acid composition of bile phosphatidylcholines in groups $\mathrm{C}, \mathrm{CO}_{20}, \mathrm{~L}_{20}$ and $\mathrm{MT}_{20}$

In these groups, PC always accounted for about 88 p. $100 \pm 2.8$ p. 100 of the total PL; they were analyzed in bile samples collected during the first 6 hrs.

TABLE 4

Fatty acid composition of biliary phosphatidylcholines (bile was collected for $6 \mathrm{hrs}$ ) in the 4 groups

\begin{tabular}{|c|c|c|c|c|c|}
\hline \multirow{2}{*}{ Fatty acids } & \multicolumn{5}{|c|}{ Groups } \\
\hline & c & $\mathrm{CO}_{20}$ & & $\mathrm{~L}_{20}$ & $\mathrm{MT}_{20}$ \\
\hline$<16: 0 \ldots \ldots \ldots \ldots$ & $1.0 \pm 0.3$ & & & & \\
\hline $16: 0 \ldots \ldots \ldots$ & $39.4 \pm 1.2$ & $39 \pm 1.4$ & & $41.1 \pm 2.1$ & $44.5 \pm 2$ \\
\hline $16: 1 \ldots \ldots \ldots$ & $3.7 \pm 0.9$ & traces & & traces & $4.1 \pm 0.9$ \\
\hline $18: 0 \ldots \ldots \ldots$ & $5.9 \pm 0.9$ & $6.4 \pm 0.9$ & & $6.5 \pm 1.0$ & $8.7 \pm 1.0$ \\
\hline $18: 1 \ldots \ldots \ldots \ldots$ & $10.8 \pm 0.9$ & $6.5 \pm 0.9^{* *}$ & & $13.8 \pm 1.2$ & $18.7 \pm 1 * *$ \\
\hline $18: 2 \ldots \ldots \ldots$ & $28.2 \pm 1.2$ & $34.6 \pm 1.8$ & ** & $26.0 \pm 1.3$ & $20.0 \pm 1.2$ \\
\hline $20: 4 \ldots \ldots \ldots \ldots$ & $11.0 \pm 1$ & $13.5 \pm 1.1$ & & $12.8 \pm 1.1$ & $4.0 \pm 0.8^{* *}$ \\
\hline Unsaturated ........ & $53.7 \pm 6.4$ & $54,6 \pm 6.1$ & & $52.6 \pm 6.7$ & $46.8 \pm 6.9 * *$ \\
\hline
\end{tabular}

Each value represents the mean \pm SE of 4 to 6 rats.

** $\mathrm{P}<0.01$.

Changes in the fatty acid pattern of these PC depended on the diets fed. However, a similar composition was found in groups $C$ and $L_{20}$. In group $\mathrm{CO}_{20}$, the linoleic acid content was higher than in the other groups at the expense of oleic acid. The highest percentages of palmitic, stearic and oleic acids appeared in group $M T_{20}$ where the value of arachidonic acid was very low. The total degree of $P C$ unsaturation was very similar (52 to 54 p. 100 ) in groups $C, \mathrm{CO}_{20}$, and $\mathrm{L}_{20}$, but was slightly lower in group $\mathrm{MT}_{20}$ (46.8 p. 100).

C. Output of bile salts, cholesterol and phospholipids during $6 \mathrm{hrs}$ collection (table 5).

Significant differences in the volume of bile secreted during $6 \mathrm{hrs}$ (table 5) were only found in the groups eating high-fat diets; the highest value was observed in group $\mathrm{CO}_{20}$. 
TABLE 5

Bile flow rate over a 6-hr period in the different groups ( $\mathrm{ml} / \mathrm{kg}$ body weight)

\begin{tabular}{ccccc}
\hline $\mathrm{C}$ & $\mathrm{CO}_{7}$ & $\mathrm{CO}_{20}$ & $\mathrm{~L}_{20}$ & $\mathrm{MT}_{20}$ \\
\hline $15.53 \pm 1.05$ & $16.27 \pm 1.23$ & $18.42 \pm 0.16$ & $13.34 \pm 0.56$ & $14.73 \pm 0.97$ \\
Comparison* & $\ldots$ & $\mathrm{CO}_{7} \simeq \mathrm{CO}_{20}$ & $\mathrm{CO}_{20}>\mathrm{L}_{20} \simeq \mathrm{MT}_{20}$ & \\
\hline
\end{tabular}

$* \mathrm{~F}=5.40, \mathrm{p}<0.05$.

Analysis of bile collected over a $6 \mathrm{hrs}$ period from the various groups (fig. 1) indicated that the orders of total output (per $\mathrm{kg} \mathrm{bw}$ ) were as follows : BS : $\mathrm{CO}_{20}=$

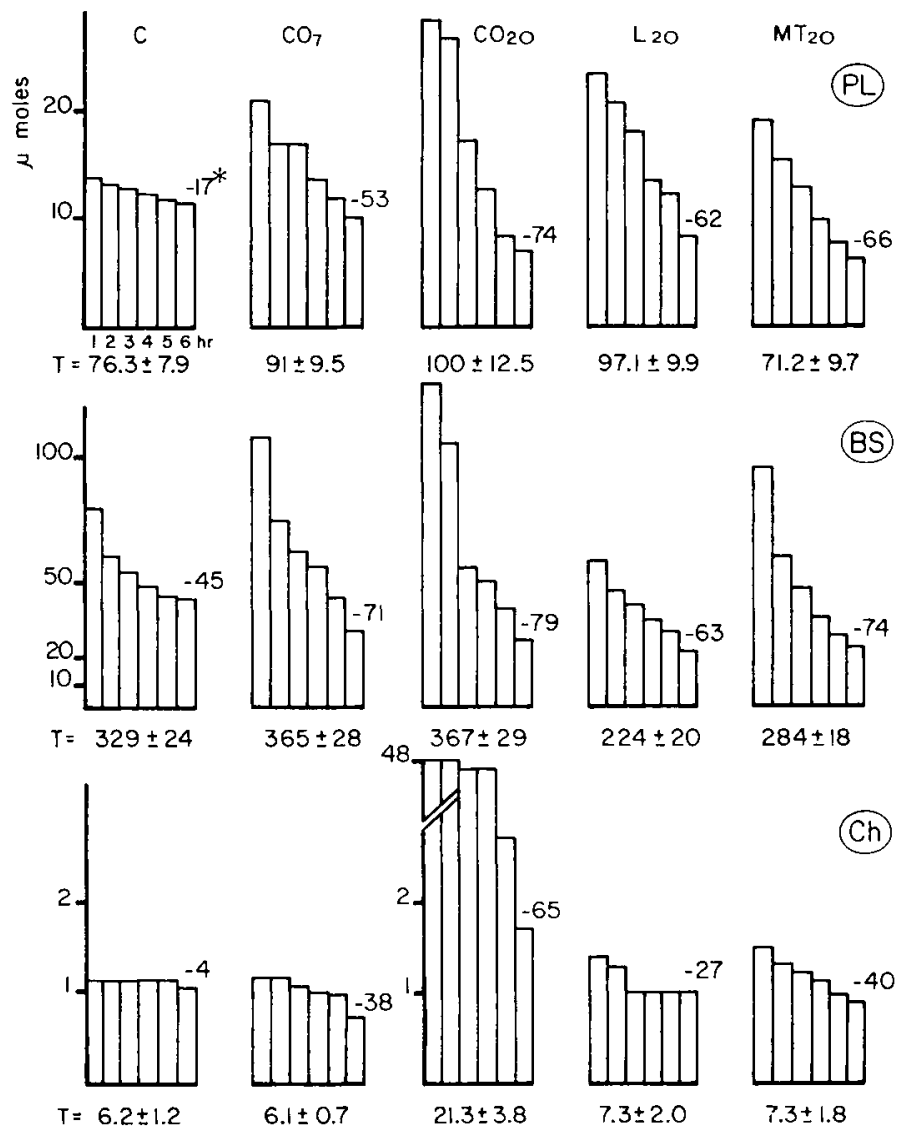

FIG. 1. - Output of BS, Ch and PL ( $\mu$ moles $/ \mathrm{kg}$ bw) during inferruption of enterohepatic circulation! $(0-6, \mathrm{hr}$ ) Each value represents the mean of 4 to 6 rats. For the sake of clarity, SEM have been omitted from the figure but they always revealed differences smaller than 12 p. 100. $T=$ total output in $\mu$ moles for $6 \mathrm{hrs}^{*}$ decrease in p. $100=\frac{(\mu \text { moles at } 1 \mathrm{hr}-\mu \text { moles at } 6 \mathrm{hrs}) \times 100}{\mu \text { moles at } 1 \mathrm{hr}}$. 
$\mathrm{CO}_{7}>\mathrm{C}>\mathrm{MT}_{20}>\mathrm{L}_{20} ; \mathrm{Ch}: \mathrm{CO}_{20}>\mathrm{MT}_{20}=\mathrm{L}_{20}>\mathrm{C}=\mathrm{CO}_{7} ; \mathrm{PL}: \mathrm{CO}_{20}=$ $\mathrm{CO}_{7}=\mathrm{L}_{20}>\mathrm{C}=\mathrm{MT}_{20}$.

Generally, BS and PL outputs decreased from the beginning of bile collection to the end, especially as the initial value was higher, although the PL output in the controls was quite constant during the first $5 \mathrm{hrs}$ of collection and decreased later. Ch ouptut was constant in time in groups $C$ and $L_{20}$, decreased slightly in groups $M_{20}$ and $\mathrm{CO}_{7}$, and considerably in group $\mathrm{CO}_{20}(65$ p. 100 between the lst and $6 \mathrm{hrs}$ ).

\section{Discussion.}

The results concerning bile flow rate and the output of BS, Ch and PL in bile, collected during the first hour after bile duct catheterization, represent normal bile secretion in intact rats fed various diets. Our findings indicate that the amount and type of dietary fat do not significantly affect either bile flow rate or BS output, although in the $4 \mathrm{groups}$ fed semi-purified diets, the highest and lowest volumes of bile secreted in $1 \mathrm{hr}$ were observed in groups $\mathrm{CO}_{20}$ and $\mathrm{L}_{20}$, respectively. Moreover, the bile flow rate in a 6 hrs collection (table 5) increased in group $\mathrm{CO}_{20}$ as compared to groups $\mathrm{L}_{20}$ $\mathrm{MT}_{20}$.

On the one hand, these observations agree with previous studies on rats (Paul and Ganguly, 1976) or monkeys (Redinger et al., 1971) showing that feeding polyunsaturated fats leads to increased bile flow; and on the other hand with that of Davis et al. (1977) which demonstrated that feeding lard induced a decline of bile flow rate as compared to the control rats.

Our results on biliary $\mathrm{Ch}$ and $\mathrm{PL}$ (output during first bile collection and absolute and relative concentrations) and also on relative BS concentrations show that these parameters were significantly influenced by the amount and type of the diefary fat. Thus, all these values were correlated with the percentage of corn oil in the diet (comparison of groups $\mathrm{CO}_{20}$ and $\mathrm{CO}_{7}$ ), and after feeding high-fat diets the $\mathrm{L}_{20}$ diet produced an increase of absolute and relative $\mathrm{PL}$ concentrations in bile. No single explanation can be offered to account for this fact. Rat intake of high-fat diets was similar and the differences found among these three groups only depended on the type of dietary fat.

Conflicting data have been published concerning the effects of various dietary fats on the absolute concentrations and the output of biliary components. In our opinion, this discrepancy is due to the use of different animal species and to the different types and amounts of dietary fats. Thus, we confirm the data of Paul and Ganguly (1976) in rats fed polyunsaturated fats : the absolute concentrations of biliary $\mathrm{Ch}$ increase and BS level remains constant. Contrary to our results, those authors found no appreciable difference in absolute biliary PL concentration in rats fed safflower oil or coconut oil, but the proportion of dietary fat was 10 p. 100 by weight instead of 20 p. 100 as in our experiments. On the other hand, an increase of the absolute BS concentration was observed in monkeys after feeding polyunsaturated fats (Redinger ef al., 1971) and, contrary to our data, no variation in Ch secretion was found. In addition, Osuga et al. (1976) obtained results conflicting with those of Redinger et al. (1971) in monkeys fed different fats. 
In the present work, relative BS concentration in the first bile collection (significant differences among the various groups) in rats fed high-fat diets does not depend on the unsaturation degree of the fat fed because with the $\mathrm{MT}_{20}$ diet (rich in saturated and monounsaturated fatty acids) that concentration was close to the level found in group $\mathrm{CO}_{20}$ (the most unsaturated fat used). Our present findings show the total effect of different dietary fats on bile output and composition, without taking into account their sterol content : phytosterols in corn oil $(8.95 \mathrm{mg} / \mathrm{g})$, cholesterol in animal fats (about $9.0 \mathrm{mg} / \mathrm{g}$ in lard or mutton tallow), and non-identified sterols in the commercial diet $(88 \mathrm{mg} / 100 \mathrm{~g})$. Thus, each rat ingested about $27 \mathrm{mg}$ of phytosterols/day in group $\mathrm{CO}_{20}, 27 \mathrm{mg}$ of cholesterol/day in group $\mathrm{L}_{20}$ or $\mathrm{MT}_{20}$, and $22 \mathrm{mg}$ of sterols in group $\mathrm{C}$. Dietary plant sterols reduce the intestinal $\mathrm{Ch}$ absorption and consequently increase the hepatic transformation of $\mathrm{Ch}$ into biliary acids; this property may explain the effect of corn oil on bile composition.

Bile flow rate is determined by the bile salts excretory rate; our results concerning these parameters confirm this view, particularly in the group $\mathrm{CO}_{20}$ during the first bile collection in which the highest BS values $(31.6 \mu$ moles) and bile flow rate $(0.92 \mathrm{ml})$ were found. In the prolonged collection of bile, however, these parameters are not always correlated. Moreover, in agreement with Wagner et al. (1976), our data (tables 2 and 3 ) indicate that BS, Ch and PL are not excreted in the bile in fixed proportions. A kinetic analysis (fig. 1), useful in quantifying biliary lipid and BS secretion, provided additional proof of these conclusions.

The effects of interrupting the enterohepatic bile circulation in the five groups during 6 hrs were different and, as expected, BS, Ch and PL secretion rates dropped, especially when the initial concentrations were higher, although $\mathrm{Ch}$ secretion remained almost constant in group $C$. While the whole pool of BS could not be quantified in $6 \mathrm{hrs}$ of collection (10 to $11 \mathrm{hrs}$ would have been necessary), it is striking that the output of BS (about $365 \mu$ moles) and PL (91 to $100 \mu$ moles) was similar in groups $\mathrm{CO}_{7}$ and $\mathrm{CO}_{20}$. In fact, the addition of small amounts of polyunsaturated fats to the diet had a considerable effect on the biliary PL and BS secretion and also on bile flow rate, the highest values of which were observed in groups $\mathrm{CO}_{20}$ and $\mathrm{CO}_{7}$.

In all cases, bile samples fell within the micellar phase when the relative concentrations of the three biliary components were plotted on a triangular coordinate (Admirand and Small, 1968), even in group $\mathrm{CO}_{20}$ in which the molar ratio $\mathrm{PL} / \mathrm{Ch}$ was very low.

As the molar ratios PC/PL were identical in all the bile samples examined (89 to 91 p. 100), we can conclude that dietary fats have no effect on the distribution of biliary PL. In all the groups, the major fatty acids of these PC were palmitic and linoleic acids; these results confirm previous findings in men (Blomstrand and Ekdahl 1960 ; Balint et al., 1965) and in rats (Olsson et al., 1973 ; Paul and Ganguly, 1976). The variations in the percentages of linoleic and saturated acids of biliary PC depended on the type of fat in the diet, thus supporting previous data (Glenn ef al. 1964 ; Dam ef al., 1967 ; Osuga ef al., 1976) obtained in mammals.

From these experiments, in which the proportion of dietary protein was constant (17 p. 100), we can conclude that dietary fats generally interfere with the synthesis and secretion of biliary components; it is particularly apparent that feeding a 
20 p. 100 unsaturated fat diet leads to increase phospholipid and cholesterol excretion through bile. Moreover, a 20 p. 100 lard diet increases the output and concentration of biliary PL and has a tendency to decrease the bile flow rate.

Reçu en mars 1979.

Accepté en mai 1979.

Acknowledgements. - Thanks are due to Dr. P. Astorg (Chargé de recherche, INRA, Dijon) for assistance in the analysis of variance. This study was supported by DGRST grant $n^{\circ} 77-7-0460$.

Résumé. Le débit de la bile et des 3 composants biliaires (sels biliaires, phospholipides et cholestérol) sécrétés pendant la première heure qui suif le cathétérisme du canal cholédoque, a été déterminé chez des rats conscients soumis à un régime commercial ou à des régimes semi-purifiés contenant, soit 7 ou 20 p. 100 d'huile de maïs, soit 20 p. 100 de saindoux ou de suif de mouton. Dans ces conditions, le débit de la bile et des sels biliaires ne montre pas de différences significatives entre les divers lots ; par contre, le débit de cholestérol et, à un moindre degré, celui des phospholipides, augmentent de façon significative lorsque l'huile de maïs passe de 7 à 20 p. 100 dans le régime ; par rapport à ce dernier lot, les débits de ces 2 composants sont inférieurs dans les lots «saindoux 》 et « suif ». Parmi les lots soumis aux régimes à 20 p. 100 de graisses, on observe dans la bile, d'une part que les concentrations absolue et relative en phospholipides sont les plus élevées dans le lot « saindoux», d'autre part que la concentration absolue en cholestérol est identique dans les lots « saindoux » et « suif », celle-ci étant inférieure à celle trouvée dans le lot « huile de maïs ». Les concentrations relatives en sels biliaires présentent des différences significatives entre les lots recevant les régimes semi-purifiés ; la valeur la plus élevée est rencontrée dans les lots « suif » et «huile de maïs » (20 p. 100). La proportion de lécithines par rapport aux phospholipides totaux biliaires est constante dans tous les lots, mais la composition en acides gras de ces lécithines varie selon la nature des graisses du régime. Au cours d'une interruption du cycle entérohépatique de $6 \mathrm{~h}$, la sécrétion des sels biliaires et des phospholipides biliaires diminue du commencement à la fin de la collecte, d'autant plus que les valeurs initiales sont plus élevées. La sécrétion du cholestérol varie moins, sauf dans le lot à 20 p. 100 d'huile de maïs, où elle décroît avec le temps.

De ces expériences, dans lesquelles la proportion de protéines dans les régimes était constante (17 p. 100), nous pouvons conclure que les graisses du régime jouent un rôle sur la synthèse et la sécrétion des constiłuants biliaires; l'administration du régime à 20 p. 100 d'huile entraîne une augmentation de l'excrétion du cholestérol et des phospholipides biliaires ; l'administration d'un régime à 20 p. 100 de saindoux produit une augmentation de la concentration en phospholipides de la bile et une tendance à réduire le débit biliaire.

\section{References}

ADMIRAND W. H., SMALL S. M., 1968. The physiochemical basis of cholesterol gallstone formation in man. J. clin. Invest., 47, 1043-1052.

ARMSTRONG W. D., VAN PILSUM J., KEYS A., GRANDE F., ANDERSON J. T., TOBIAN L., 1957. Alteration of serum cholesterol by dietary fats. Proc. Soc. exp. Biol. Med., 96, 302-306.

AVIGAN J., STEINBERG D., 1965. Sterol and bile acid excretion in man and the effects of dietary fat. J. clin. Invest., 44, 1845-1856.

BALINT J. A., KYRIAKIDES E. C., SPITZER H. L., MORRISON E. S., $1965 . \quad$ Lecithin fatty acid composition in bile and plasma of man, dogs, rats and oxen. J. Lipid Res., 6, 96-99. 
BLOMSTRAND R., EKDAHL P., 1960. Fatty acid pattern of human bile under normal and patholcgical conditions. Proc. Soc. exp. Biol. Med., 104, 205-209.

BOUCROT P., 1972. Is there an entero-hepatic circulation of the bile phospholipids ? Lipids, 6, 282288.

BYERS S. D., FRIEDMAN M., 1958. Bile acid metabolism dietary fats and plasma cholesterol levels. Proc. Soc. exp. Biol. Med., 98, 523-526.

DAM H., KRUSSE I., JENSEN K. M., KALLENHAUGE H. E., 1967. Studies on human bile. II Influence of two different fats on the composition of human bile. Scand. J. clin. Lab. Invest., 19, 367-378.

DAVIS J. W., ELLIOTT W. H., FOELSCH J. M., RUMINSKI P., 1977. Role of diet on composition of rat bile. Fed. Proc., 36, 1143.

DELSAL J., 1944. Nouveau procédé d'extraction des lipides du sérum par le méthylal. Application aux microdosages du cholestérol total, des phosphoaminolipides et des protéines. Bull. Soc. Chim. biol., 26, 99-105.

DOWLING R. H., COWLEY D., WHYTE J., CAMPBELL C. B., 1971. The effect of dietary fat on bile composition in monkeys with an intact enterohepatic circulation. Eur. J. clin. Invest., 1 (abstr. 30) 369-370.

FOLCH J., LEES M., SLOANE-STANLEY G. H., 1957. A simple method for the isolation and purification of total lipids from animal tissues. J. biol. Chem., 226, 497-509.

GLENN J. L., CHRISTENS F., DAM H., 1964. Effect of dietary lipids on the fatty acid composition of liver and bile phosphatides of hamsters. Alimentary production of gallstones in hamsters. Biochim. biophys. Acta, 84, 753-755.

GLENN J. L., DAM H., 1965. Influence of dietary lipids on the fatty acid composition of neutral lipids and phosphatides in chick liver and bile. J. Nutrition, 86, 143-153.

GORDON B. A., KUKSIS A., BEVERIDGE J. M. R., 1964. The effect of dietary fat on bile acid metabolism in man. Can. J. Biochem., 42, 897-905.

HO K. J., DRUMMOND J. L., 1975. Circadian rhythm of biliary excretion and its control mechanisms in rats with chronic biliary drainage. Am. J. Physiol., 229, 1427-1437.

KINSELL L. W., PARTRIDGE J., BOLING L., MARGEN S., MICHAELS G., 1952. Dietary modification of serum cholesterol and phospholipid levels. J. clin. Endocr., 12, 909-913.

KLAASSEN C. D., 1970. Studies on the increased biliary flow by phenobarbital in rats. J. Pharmacol. exp. Ther., 176, 743-751.

KLAASSEN C. D., 1971. Does bile acid secretion determine canalicular bile production in rats? Am. J. Physiol., 220, 667-673.

LINDSAY O. B., BIELY J., MARCH B. E., 1969. Excretion of bile acids by cockerels fed different lipids. Poultry Sci., 48, 1216-1222.

LINDSTEDT S., AVIGAN J., GOODMAN D. S., SJÖVALL J., STEINBERG D., 1965. The effect of dietary fat on the turnover of cholic acid and on the composition of the biliary bile acids in man. J. clin. Invest., 44, 1754-1768.

MACHEBOEUF M., DELSAL J., 1943. Sur le dosage de très petites quantités de phosphore dans les matières organiques. Bull. Soc. Chim. biol., 25, 116-125.

MCGOVERN R. F., QUACQUENBUSH F. W., 1973. Turnover of bile acids in the hypercholesterolemic rat as influenced by saturation of dietary fat. Lipids, 8, 466-469.

MOORE R. B., ANDERSON J. T., TAYLOR H. L., KEYS A., FRANTZ I. D. Jr, $1968 . \quad$ Effect of dietary fat on the fecal excretion of cholesterol and its degradation products in man. J. clin. Invest., 47, 1517-1534.

MYANT N. B., EDER H. A., 1961. The effect of biliary drainage upon the synthesis of cholesterol in the liver. J. Lipid Res., 2, 363-368.

OLSSON O., BOUCROT P., CLÉMENT J., 1973. Obtention quantitative des lipides biliaires : application à l'étude de ceux de rat. Biochimie, 55, 491-496.

OSUGA T., PORTMAN O. W., TANAKA N., ALEXANDER M., OCHSNER A. J., 1976. The effect of diet on hepatic bile formation and bile acid metabolism in squirrel monkeys with and without cholesterol gallstones. J. Lab. clin. Med., 88, 649-661.

PAUL R., GANGULY J., 1976. Effect of unsaturated lipids of the bile flow and biliary excretion of cholesterol and bile salts in rats. Chemist. Phys. Lipids, 17, 315-323.

QUACQUENBUSH F. W., PAWLOWSKI M. D., 1960. Effects of purified linoleic ester on cholesterol in the rat. J. Nutrition, 72, 196-202. 
REDINGER R. N., HERMAN A. H., SMALL D. M., 1971. Effect of diet on bile composition in the rhesus monkey. Gostroenterology, 60, 198.

SHEFER S., HAUSER S., BEKERSKY I., MOSBACH E. H., 1969. Feedback regulation of bile acid biosynthesis in rat. J. Lipid Res., 10, 646-655.

SHIODA R., WOOD P. D. S., KINSELL L. W., 1967. Human biliary output of lipids in relation to diet. Fed. Proc., 26, 303.

SODHI H. S., WOOD P. D. S., SCHLIEFF G., 1967. Plasma, bile and fecal sterol in relation to diet. Metabolism, 16, 334.

TALALAY P., 1960. Enzymatic analysis of steroid hormones. Methods biochem. Anal., 8, 119-143.

WAGNER C. I., TROTMAN B. W., SOLOWAY R. D., 1976. Kinetic analysis of biliary lipids excretion in man and dog. J. clin. Invest., 57, 473-477.

WHEELER H. O., KING K. K., 1972. Biliary excretion of lecithin and cholesterol in the dog. J. clin. Invest., 51, 1337-1350. 